\title{
Exile and Expatriates in Robin Jenkins' Novels
}

Exil et expatriés dans les romans de Robin Jenkins

\section{Bernard Sellin}

\section{(2) OpenEdition}

1 Journals

\section{Electronic version}

URL: https://journals.openedition.org/etudesecossaises/231

DOI: 10.4000/etudesecossaises.231

ISSN: 1969-6337

\section{Publisher}

UGA Éditions/Université Grenoble Alpes

\section{Printed version}

Date of publication: 30 September 2010

Number of pages: 129-138

ISBN: 978-2-84310-173-1

ISSN: 1240-1439

\section{Electronic reference}

Bernard Sellin, "Exile and Expatriates in Robin Jenkins' Novels", Études écossaises [Online], 13 | 2010, Online since 30 September 2011, connection on 11 April 2023. URL: http://journals.openedition.org/ etudesecossaises/231; DOI: https://doi.org/10.4000/etudesecossaises.231

All rights reserved 


\section{Exile and Expatriates in Robin Jenkins' Novels}

Scotland has a long history of migration, not only to England, but also to the rest of the world. There is a "migrant tradition" which has been well documented by historians or sociologists. Studies devoted to Scotland's involvement in the Empire or to the Scottish diaspora show that emigration has become a leitmotiv which is difficult to ignore. ${ }^{1}$

Writers themselves have often either been directly affected by this migration or have felt the need to address Scotland's relations with the outside world. ${ }^{2}$ One example is Robin Jenkins (1912-2005), presented by Isobel Murray as Scotland's finest contemporary novelist. ${ }^{3}$ In a lecture entitled "The Novelist's Quest for a Suitable Theme" Jenkins himself made this unexpected comment on the subject:

It is a curious fact that Scots novelists have never regarded it as their duty to write about Scotland. I mentioned Sir Compton (Mackenzie), who presides over the literary scene in Edinburgh; but his reputation was established by books that had nothing to do with Scotland. Mr Eric Linklater is another as likely to write about the Fidji Islanders as about his countrymen. ${ }^{4}$

Taken out of context, the statement may seem surprising. The sarcastic tone and exaggeration should not blur the point which Jenkins wanted to make: the necessity of considering Scottish society as a valid subject of fiction as long as it was rendered truthfully. In another essay he added: "In the past Smollett, Scott and even Stevenson, drew a large proportion of their material from outside their native country with, I believe, a

1. Tom Devine (ed.), Scottish Emigration and Scottish Society, Edinburgh, 1992.

Marjory Harper, Adventurers and Exiles: The Great Scottish Exodus, Profile Books, 2004.

Billy Kay, The Scottish World, Edinburgh and London, Mainstream Publishing, 2006.

2. For general criticism on the subject see Nigel Leask, "Scotland's Literature of Empire and Emigration, 1707-1918", in The Edinburgh History of Scottish Literature, vol. 2, pp. 153-62.

Douglas S. Mack, Scottish Fiction and the British Empire, Edinburgh, Edinburgh University Press, 2006.

3. Isobel Murray, "Robin Jenkins obituary", The Scostman, 1 March 2005.

4. Robin Jenkins, "The Novelist's Quest for a Suitable Theme", Proceedings of the Annual Conference, Coatbridge, Scottish Library Association, 1956, p. 21. 
weakening effect on their work, and on Scottish literature." 5 Here again his intention was to invite authors to write primarily about Scotland. The novelist should write about what he knows best, he added, quoting Milton: "In my own country, where I most desire." 6

These judgements were expressed in the mid-fifties, when Jenkins was still at the beginning of his career, despite having already published some of his best books, among them The Thistle and the Grail (1954), The ConeGatherers (1955) and Guests of War (1956), all of which offer a perceptive, though disenchanted, portrait of the Scottish scene.

And yet, shortly after the aforementioned declarations, Robin Jenkins himself was to break links with his home country, thus giving his life and work an unexpected turn. Though we do not know the actual reasons for his departure, Jenkins often expressed disillusion with Scotland. On several occasions he had vented his frustrations about the limitations of the Scottish scene and its imaginative possibilities, even though, ultimately, he recommended novelists "to stay at home". 7

An abrupt change in his teaching career took him to several foreign countries. In 1957 he was appointed to a position in Kabul, Afghanistan. He was then offered the post of Cultural Officer with the British Council in Barcelona. This was, in his own words, a "plum job", which he nevertheless gave up after two years, to everybody's astonishment. The decision was apparently motivated by the fact that most of his time was taken up with administrative work and representation, leaving him little opportunity to write. He returned to live in Scotland for another two years but was restless and longed to discover the Far East. From 1963 to 1968, Robin Jenkins then lived in Borneo, the longest and most enjoyable of his stays abroad.

Throughout those years Jenkins never stopped writing and the result was eight novels and one collection of short stories, all dealing with foreign themes. These appeared between 1960 and 1974, and were all set in the countries which the author had visited. ${ }^{8}$ They gave his work a new form and inspiration which contrasted with the Scottish novels though the Scottish identity remains present in the background and the general philosophy remains the same.

On the whole, this second period has received little critical attention, presumably because it does not affect readers as intimately as the

5. Robin Jenkins, "Novelist in Scotland", Saltire Review, vol. 2, no. 5, 1955, p. 7.

6. Ibid., p. 7.

7. Robin Jenkins, "The Novelist's Quest for a suitable Theme", Proceedings of the Annual Conference, Coatbridge, Scottish Library Association, 1956, p. 25.

8. One novel belonging to that background was published late in 1995, Leila. 
Scottish books, although one at least (Dust on the Paw, 1961, which deals with Afghanistan) has been highly praised and even compared with E.M. Forster's Passage to India. ${ }^{9}$ It is also true that for some years many of the books were out of print. Unexpectedly, today's political tensions in Afghanistan are lending new interest to some of them. It is noticeable that only one novel is available in French, the recently translated Some Kind of Grace (1960), also set in Afghanistan. ${ }^{10}$ One is set in Catalonia (The Sardana Dancers, 1964), while the rest are all concerned with the Far East, and particularly Malaysia (Borneo).

Bearing in mind the circumstances of Jenkins' travels, we should not expect to come across a problematic of exile as defined by Edward Said: "the unhealable rift forced between a human being and a native place, between the self and its true home". ${ }^{11}$ In the same essay, Said mentions "the crippling sorrow of estrangement" associated with exile. Jenkins, on the contrary, speaks freely about his love of travelling, and about the pleasure of being in a strange city where you don't understand the language. $^{12}$

Consequently, Jenkins' novels are seldom about "exile", a word he does not often use, except ironically. Dealing with expatriates and the experience of living abroad, they therefore require a new relationship to be defined, both with the country of origin, which can even be obliterated (although this is rare), and with the country of adoption and its inhabitants, traditions, language, climate, etc. ${ }^{13}$

The subject can be examined from two opposite angles. On the one hand we have the novelist writing about his own experience at one given moment, living in a foreign country which he has, if not selected, at least accepted, experiencing a situation which he endorses and which has therefore little to do with Said's sense of loss. The separation is known to be temporary. The expatriate can put an end to it whenever he chooses and decide to return home. On the other hand we have the literary expression

9. That part of Jenkins' work has been examined by Douglas Gifford in his Scottish Literature, in English and Scots, Edinburgh University Press, 2002, pp. 850-4, and by Ingibjörg Agústsdóttir in "Full Circle: The Function of Place in the Fiction of Robin Jenkins", Terranglian Territories: Proceedings of the Seventh International conference on the Literature of Region and Nation, Frankfurt am Main, Peter Lang, 2000, pp. 179-86.

10. La colère et la grâce, Paris, Albin Michel, 2008.

11. Edward Said, Reflections on Exile and other Literary and Cultural Essays, London, Granta Books, 2001, p. 173.

12. Isobel Murray (ed.), Scottish Writers Talking, 3, Edinburgh, John Donald, 2006, p. 124.

13. On the difference between expatriate and exile, see Peter Costello: "an expatriate is someone who sloughs off his country like an old skin; an exile, on the other hand, however far he may go, has his country always on his mind." (Peter Costello quoted by Patrick Ward, op. cit., p. 11.) 
of that estrangement which presents characters who experience a similar situation to, but who are distinct from, the novelist: engineers, clerks, embassy staff, administrators, teachers. The period is usually the 1960s, a post-imperial context in which, though Britain is still in a position of authority overseas, independence has either already achieved by former colonial territories or is imminent, with the result that members of the British delegations no longer hold effective power. Only once do we come across a writer adjusting to his new life, in the person of Jonathan Broxmead in The Sardana Dancers (1964), an Englishman with whom Jenkins can hardly be suspected of sharing affinities. More interesting is the other artist of the book, the Scottish painter John Lynedoch who, better than any other character, expresses the tensions and frustrations of Scottish connections, including both the rejection of home and the emotional richness which these tensions produce. As mentioned above, Lynedoch shares some features with the author, in particular his working class background, his frustrations and uncertainties, and his absence of involvement.

Thus Jenkins' foreign novels describe the experiences of Scottish or English expatriates viewed critically by a writer who seldom considers himself as one of them, a writer who, as usual, seems to be testing his characters and particularly their abilities to adapt to a foreign world. Themes which are treated include the vulgarity of British expatriates and, in contrast, the dignity of native peoples, race and racism, prejudice, interracial relationships and especially mixed marriage, political and administrative power, corruption, and occasionally nationalism.

Obviously, there is no single model. On the contrary, Jenkins is always careful to change perspectives. For example, some novels focus on the native peoples (Dust on the Paw, The Holy Tree, Bonny Chung), while others devote their attention to the expatriates (A Far Cry From Bowmore, A Figure of Fun, The Sardana Dancers). Interracial relationships are common and are explored in many different forms ("Imelda and the Miserly Scot", The Expatriates, Dust on the Paw, "A Far Cry from Bowmore"). These works are not so much about homesickness, a necessary component of the experience of exile, as about the difficulty of breaking links with the country of adoption (The Sardana Dancers, The Expatriates).

Although the books offer many parallels between home and abroad in terms of landscape, behaviour or religion, these never appear to be the priority for the narrator. In one story (The Expatriates, p. 115) the hero is, as it were, carrying a part of Scotland with him: a Celtic cross tattooed on his arm representing St Martin's Cross in Iona. But this is an exception and, in an ironic way so characteristic of Jenkins' rejection of sentimentality, the reader learns that the tattoo was the result of an impulsive, 
though highly symbolic decision taken during a drinking spree, which, surely, reduces the commitment.

Readers seldom come across scenes of nostalgic recollection or a sense of kinship with other expatriates. One exception is to be found in the short story "A Far Cry from Bowmore", which gives its title to the whole collection, when Macpherson visits McArthur on his death bed. ${ }^{14}$ The dying man wants Macpherson to talk about his birthplace and their conversation evokes the Western Isles, Macpherson's plan of retiring on Islay, Gaelic songs, etc. A second instance is the meeting between McCleod and Kemp in Some Kind of Grace (1960). Once again, death is impending and the meeting is mediated through Gaelic, which appears here as the language of emotion and of roots. It's noticeable that many of Jenkins' expatriates are Highlanders or, at least, have Highland origins, perhaps in recollection of the part that Highlanders played in the formation of the British Empire, through their role in the military, for example, or as the result of evictions. In a review of Some Kind of Grace, James Meek makes an interesting suggestion when he parallels the Highlands with the foreign sub-culture in terms of poverty, dispossession and political exploitation. "Being an atheist among believers and a wealthy foreigner among the poor, McLeod, in the glens of Afghanistan, is a Highlander among highlanders, seeing the squalor and the dignity both as an outsider and, through history, from within". ${ }^{15}$ After all, you do not have to go a long time back to find Highlanders being treated like savages, as Meek reminds us. In the two examples mentioned here, attachment to the home country is expressed more through reference to the Highlands than to Scotland at large. This is even more restricted if we bear in mind that Bowmore is a village on Islay.

Such scenes of nostalgia are, however, scarce in Jenkins' work for the simple reason that they do not stand up to comparison with oriental values and settings. Consequently, we do not find a romantic scene of homecoming in the tradition of exilic nostalgia as exemplified in Waugh's Put out more Flags (1942). ${ }^{16}$ In this book the reader encounters the typical situation of a character who has spent most of his life overseas as a dutiful servant of the Empire and been dreaming of returning to the house he bought, "meaning to retire there when the time came". The homecoming scene is imbued with a sense of pleasant return to the past as if the stay abroad had been a mere parenthesis during which time

14. A Far Cry from Bowmore, London, Victor Gollancz, 1973, pp. 162-6.

15. James Meek, "A Scot in the Afghan glens", The Guardian, 18 September 2004.

16. Evelyn Waugh, Put out more Flags [1942], Penguin Books, 1943, pp. 90-1. Evelyn Waugh was one of Jenkins' favourite authors. 
had been suspended. The colours of home are rich and mellow and "the scent of the gillyflowers are sweet and fresh on the breeze" (pp. 90-1), we read. The place is unchanged after so many years spent abroad, still untouched by modernity. Needless to say that this description is closer to a dream than to reality but it is characteristic of exilic imagination, however ironic the passage may be.

Turning from Waugh to Jenkins' The Expatriates, the contrast can hardly be more abrupt. Not only is home nearly absent from the book but it is actually known as "Martyrs' Brae", a name which suggests not rebirth and fulfilment but death and sacrifice, in recollection of an historical episode in which two covenanters were killed long ago. The past may still be alive but it has taken a threatening form: just as someone will one day have to pay for this past murder, there is the suggestion that going home will be a form of punishment for the expatriate's betrayal of his Asian mistress.

For another family in this book, homecoming, even when temporary, becomes an ordeal when they realise that, after so many years spent abroad, they do not belong any more. The girls look like mere visitors cut off from their roots, while the father, the aptly named Bill Livingstone, realises:

with all his expatriate advantages left behind in far-off Kalimantan, he was here in Scotland purposeless and disconsolate. Living crampedly in his parents' small council house, with his wife grumbling at him most of the time, he had the sense to know that boasting of his distant Mercedes Benz would be more pathetic than impressive. ${ }^{17}$

Most of his foreign books give a harsh, sardonic view of the expatriate community where gin and lechery lead to sordid adventures and where gossip, jealousy and stupidity are the norms. Even those who mean well often find themselves trapped in their own contradictions or carried away by decisions which they can no longer control, such as Harold Moffatt in Dust on the Paw or Alistair Campbell in A Figure of Fun. For those men who have left their wives behind in Europe, there are female compensations abroad which few of them have the strength to resist. ${ }^{18}$ This critical view, however, is probably the least interesting aspect of this fiction as satirical excess tends to stifle the message.

More fundamental is the relationship which is established with the local community, although, in many cases, characters may in fact live in a

17. The Expatriates, London, Victor Gollancz, 1971, p. 78.

18. John Melrose in The Holy Tree, p. 105: "Melrose had a wife at home in Scotland to whom every month he made a generous allotment of money, out of duty, however, not love." 
ghetto of white expatriates. The point is made particularly in the only novel set in Catalonia, The Sardana Dancers. It is a complex narrative set on the Costa Brava which involves several young characters, among them two English twins, Jonathan and Madeleine Broxmead, who have been in Catalonia for some three years. They have been enjoying the sun and their new carefree life, but they also realise its emptiness. The novel touches on many themes (social class, political commitment, art, spiritual values) but one which recurs throughout is the necessity of understanding and engaging closely with other people. This is what Jonathan, a writer whose novels have been repeatedly rejected, learns at the end of the book; indeed, this realisation may be what stirs his creative genius again. The Sardana, the Catalan dance whose symbolic motif runs through the book, expresses this sense of a human communion which everybody is invited to join.

The Broxmead twins are in keeping with stereotypes of English upper middle class snobbery: wealthy, refined in speech and manners, aloof. For that reason the reader is on the lookout for any breach in their superiority complex. This happens in a double confrontation with the local Catalan community and with a Scottish painter from Glasgow, John Lynedoch.

Lynedoch, one of Jenkins' most interesting figures, fulfils the role of the powerful working class artist whose undeniable genius feeds on his own tensions and doubts. He also highlights the complex, even problematic, relationships with the native country since he carries with him a shame of his background, reasserted in the painful meeting with three Glasgow girls. "Though only four or five years his juniors, they had brought with them all the stultifying confusion, dreary bigotry, and petty arrogance of their country and class" (p. 75). In that sense, the foreign setting serves to remind characters that they cannot escape from their identity and roots. One single meeting is enough to abolish distance: "You are what you were brought up to be [...]; it's in your blood, and in the remotest crannies of your brain; you cannot get rid of it" (p. 76). Running away to Spain or the Far East will not hide this fact.

However, what one can - one must - do is open oneself to others, in a gesture that will be all the more valuable if the Other belongs to a different culture. Thus most of Jenkins' novels raise the issue of interracial or international understanding on the assumption that exile involves a double aspect of dispossession and encounter with a new culture. It is, in the words of one critic, "a cross-cultural, cross territorial and crosslinguistic experience". ${ }^{19}$ In the end, Jenkins is really more interested in

19. Kinga Olszewska, Wanderers across Language. Exile in Irish and Polish Literature of the Twentieth Century, London, Legenda, Modern Humanities Research Association and Maney Publishing, 2007, p. 1. 
this cultural confrontation than in the arrogant behaviour of his Scottish or English characters. For many of them the situation is hopeless, a mere transplantation of Western communities abroad, with many vices and few virtues. Among the former is, in the words of one character, "the characteristic British failing" of obtuseness, or "the centuries-old irremovable unawareness that other people in other countries ordered some things better". ${ }^{20}$

Jenkins has confessed that he personally found a great lesson of humility in his successive stays overseas. His books also show what poverty, disease and despair mean while pointing out the responsibilities of the local elites in terms of corruption and backwardness.

Not only does his fiction take pains to depict the arrogance, vulgarity and emptiness of expatriates, but it also attempts to draw attention to what is positive about the foreign setting. This is achieved particularly through plots involving interracial marriages or relationships, such as in Dust on the Paw, The Expatriates, The Sardana Dancers and "Imelda and the Miserly Scot", among others. Of course, having a native mistress is part of the conventional image of the expatriate but beyond that cliché we also come across situations of expatriates who genuinely fall in love with native women, an experience which often ends tragically for lack of courage and honesty ("Imelda and the Miserly Scot", The Expatriates), but which also occasionally opens prospects of redemption and human greatness. It follows that the most interesting of Jenkins' characters are those who learn something from their experiences abroad in terms of generosity, dignity, understanding and relativity. Exile then is not limited to a separation from home. It also represents, if not a union with, at least the discovery of an unknown world. For Jenkins, those who keep longing to return home (and few actually do) are relatively shallow characters. The interesting ones are those who are so radically transformed by their experience that they can no longer go back home. "To emigrate is to change, to become 'Other', different, plural', writes Patrick Ward in the context of Irish literature. ${ }^{21}$ This is also relevant for Jenkins' fiction, and we can easily draw a line between the characters who accept change and question their own identity, and, those who are unable to face this because of prejudice, rigidity or a feeling of superiority. Few of them accept the Other as he/she is, but for those that do so the consequence is an experience that thoroughly affects them, in a way reminiscent of a Joycean epiphany. Like Macpherson in "A Far Cry from Bowmore", they may return home, but utterly transformed. This transformation, though

20. Dust on the Paw, London, MacDonald, 1961, p. 51.

21. Patrick Ward, op. cit., p. 245. 
positive, is also the prelude to more dissatisfaction and frustration, the result of the intimate breach which exile has opened in the self.

Jenkins' foreign novels and stories open interesting perspectives for anybody interested in the production of this major Scottish author. They offer a view which is less grim perhaps, and one which is less obsessed with national identity and the limitations of the Scottish scene. They also offer a release and, for that reason, seem to contradict the problematic of exile with its insistence on notions of nostalgia and return, and on the pain of separation.

Leaving Scotland in the late 1950s was never regarded as a form of exile by the author, though the temptation of exile is forever present in his fiction. Like Mungo Niven at the end of A Very Scotch Affair as well as several others of his heroes, Jenkins himself never excluded the option of departing from Scotland at times of failure and despondency. From Mungo Niven's dubious attraction to a "beautiful place of banishment" to other characters' deep commitment to the foreign world, many differences can be found. What they have in common, though, is a sense of dissatisfaction with the Scottish scene which finds an outlet in its confrontation with another setting, rendered in more positive, though not at all idealistic, terms. In various forms, Jenkins' stories of expatriates tell the same message of tolerance and opening towards the rest of the world. Scots have much to learn from others and, in that sense, his fiction breaks with the stereotypes of the sentimental, nationalistic superiority of home to offer a disquieting questioning of commonly accepted values. No wonder Jenkins has been described as an "ambivalent patriot" 22 as his foreign books often depict Scottish (or English) heroes who discover more affinities with the Other than with their own people. ${ }^{23}$

\section{Bibliography}

\section{Fiction by Robin Jenkins}

Some Kind of Grace, London, Macdonald, 1960.

Dust on the Paw, London, Macdonald, 1961.

Tiger of Gold, London, Macdonald, 1962.

22. Paul Binding, "Ambivalent Patriot. The Fiction of Robin Jenkins", New Edinburgh Review, Spring 1981, pp. 20-2.

23. Though English characters are few, they are not totally absent from Robin Jenkins' fiction. Three examples of such heroes falling in love with a foreigner are Laura Johnstone in Dust on the Paw, Jonathan Broxmead in The Sardana Dancers and Andrew Sandilands in Leila. 
The Sardana Dancers, London, Jonathan Cape, 1964.

The Holy Tree, London, Gollancz, 1968.

The Expatriates, London, Gollancz, 1971.

A Far Cry from Bowmore, London, Gollancz, 1973.

A Figure of Fun, London, Gollancz, 1974.

Leila, Edinburgh, Birlinn, 1995.

La colère et la grâce, Paris, Albin Michel, 2008, trad. Françoise du Sorbier.

\section{General bibliography}

AgústsdótTiR Ingibjörg, "Full Circle: The Function of Place in the Fiction of Robin Jenkins", Terranglian Territories: Proceedings of the Seventh International conference on the Literature of region and Nation, Susanne Hagemann (ed.), Frankfurt am Main, Peter Lang, 2000, pp. 179-86.

Binding Paul, "Ambivalent Patriot. The Fiction of Robin Jenkins", New Edinburgh Review, Spring 1981, pp. 20-2.

Devine Tom (ed.), Scottish Emigration and Scottish Society, Edinburgh, 1992.

Gifford Douglas, Dunnigan Sarah, and MacGillivray Alan, Scottish Literature, Edinburgh, Edinburgh University Press, 2002.

Harper Marjory, Adventurers and Exiles: The Great Scottish Exodus, Profile Books, 2004.

Jenkins Robin, "Novelist in Scotland", Saltire Review, vol. 2, no. 5, 1955, pp. 7-10.

_-, "The Novelist's Quest for a Suitable Theme", Proceedings of the Annual Conference, Coatbridge, Scottish Library Association, 1956, pp. 21-7.

KaY Billy, The Scottish World, Edinburgh and London, Mainstream, [2006], 2008.

LEASK Nigel, "Scotland's Literature of Empire and Emigration, $1707-$ 1918", in The Edinburgh History of Scottish Literature, vol. 2, pp. 153-62.

Mack Douglas S., Scottish Fiction and the British Empire, Edinburgh, Edinburgh University Press, 2006.

Meek James, "A Scot in the Afghan glens", The Guardian, 18 Sept. 2004.

Murray Isobel (ed.), Scottish Writers Talking, 3, Edinburgh, John Donald, 2006, pp. 101-46.

_-, "Robin Jenkins obituary", The Scotsman, 1 March 2005.

Olszewska Kinga, Wanderers across Language. Exile in Irish and Polish Literature of the Twentieth Century, London, Legenda, Modern Humanities Research Association and Maney Publishing, 2007.

SAID Edward, Reflections on Exile and other Literary and Cultural Essays, London, Granta Books, 2001.

Ward Patrick, Exile, emigration and Irish Writing, Dublin, Irish Academic Press, 2002.

Waugh Evelyn, Put out more Flags [1942], Penguin Books, 1943. 